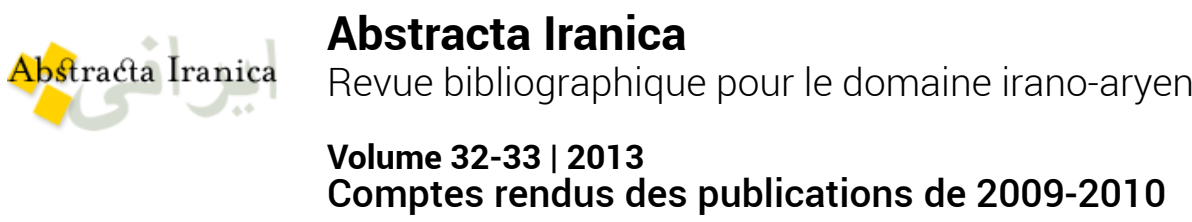

\title{
Malek Iradj Mochiri. Monnaies dite de 'Khusraw IV'
}

\author{
Nikolaus Schindel
}

\section{OpenEdition}

\section{Journals}

Electronic version

URL: http://journals.openedition.org/abstractairanica/40557

DOI: 10.4000/abstractairanica.40557

ISSN: 1961-960X

\section{Publisher:}

CNRS (UMR 7528 Mondes iraniens et indiens), Éditions de l'IFRI

\section{Printed version}

Date of publication: 1 December 2013

ISSN: 0240-8910

\section{Electronic reference}

Nikolaus Schindel, « Malek Iradj Mochiri. Monnaies dite de 'Khusraw IV' », Abstracta Iranica [Online], Volume 32-33 | 2013, document 189, Online since 01 July 2016, connection on 04 October 2020. URL : http://journals.openedition.org/abstractairanica/40557; DOI : https://doi.org/10.4000/ abstractairanica.40557

This text was automatically generated on 4 October 2020 .

Tous droits réservés 


\title{
Malek Iradj Mochiri. Monnaies dite de 'Khusraw IV'
}

\author{
Nikolaus Schindel
}

\section{REFERENCES}

Malek Iradj Mochiri. « Monnaies dite de 'Khusraw IV' ». Res Orientales XIX, Sources for the History of Sasanian and Post-Sasanian Iran. Bures-sur-Yvette / Leuven, GECMO / Peeters Press, 2010, p. 177-201.

1 The author describes a set of Late Sasanian drachmas showing a bearded bust with, on the obverse, the name Hosrow and, on the reverse, the standard reverse types used since the 11th regal year of Hosrow II. Since their dates range from year 2 to 10 , they were not issued during the reign of Hosrow II. The author suggests that their issue occurred during the reign of the last Sasanian King of Kings, Yazdgerd III (632-651) and continued well into the Arab period.

\section{AUTHORS}

NIKOLAUS SCHINDEL

Österreichische Akademie der Wissenschaften, Wien 